Part 2.

History of the International Latitude Service, Bureau International de l'Heure, International Earth Rotation Service and Polar Motion Applications 


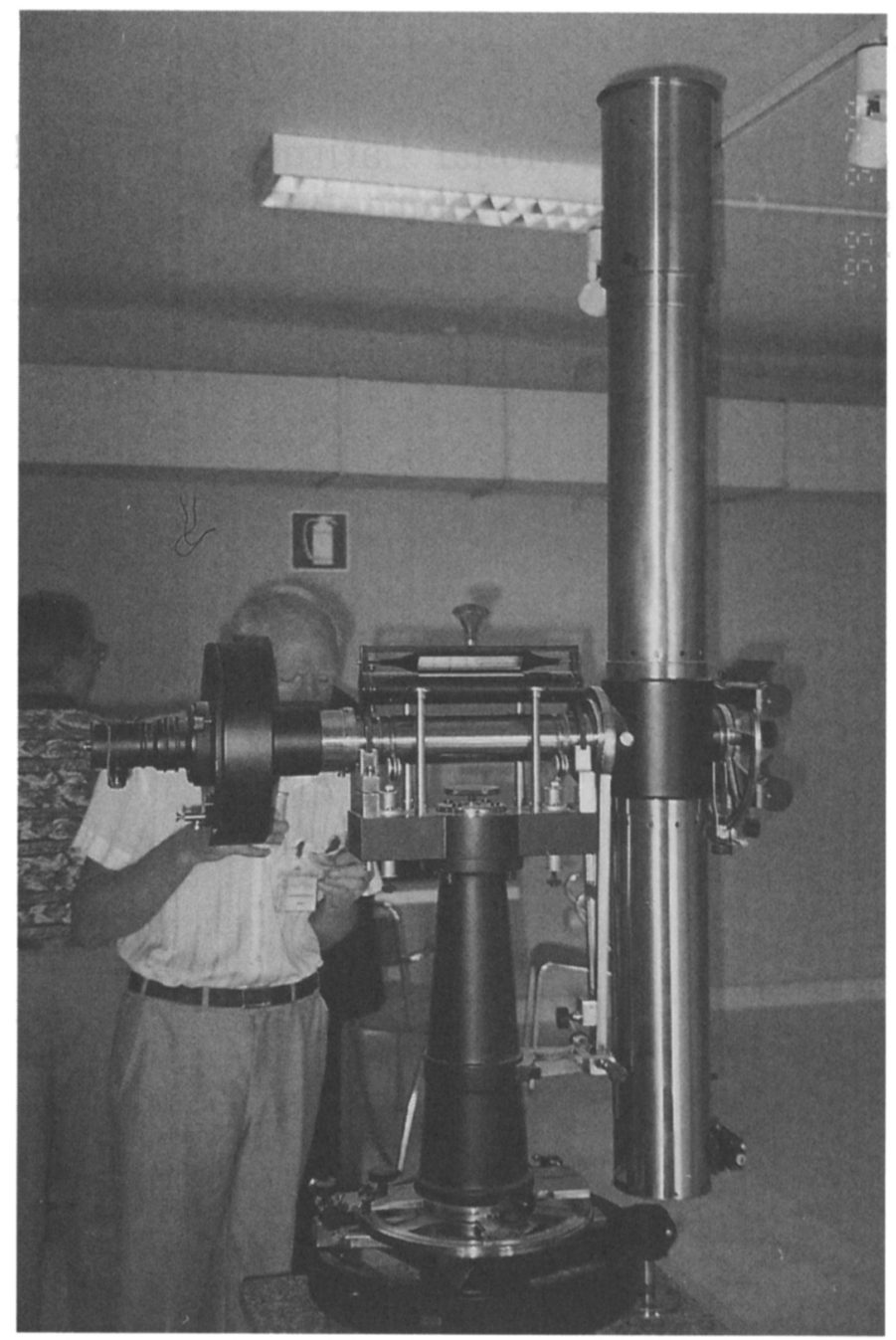

N. Sidorenkov with Visual Zenith Telescope 


\title{
The Period of Organization of the International Latitude Service: $1889-1899$
}

\author{
E. Proverbio
}

Dipartimento di Fisica, Università di Cagliari

Osservatorio Astronomico di Brera, Milano

\section{The preparatory period and latitude variations in the free (inde- pendent) stations}

Around 1880 , and for some time after that, the possibility of revealing a variation in latitude as a consequence of a separation of the instantaneous rotation axis from the Earth's axis of inertia gave rise to much perplexity due to the complexity of the problem and the existence of non-negligible and hard-to-find systematic errors in observations of a personal and instrumental nature. These errors also depended on effects of refraction and imprecise knowledge of star declinations.

To this must be added the fact that the very idea that the rotational axis and the axis of inertia were distinct and in relative motions raised difficult problems of a physical and theoretical nature. At that time the idea of the Earth's rigidity was still generally accepted and, even admitting the hypothesis of an Earth endowed with sufficient elasticity and plasticity, the theory of which had been partly examined by G.H. Darwin (1), it was then almost impossible, just as it still is today, to create a model of the movements of mass inside the Earth which could offer an explanation of possible aperiodic and secular variations. In reality, more than on the existence of periodic variations, the attention and interest of geodesists and astronomers was in those years focused on the problem of the existence or non-existence of secular variations in the Earth's principal axis.

In this climate of uncertainty, at the Conference of the International Geodetic Association (IGA), held in Rome in 1883, Emanuele Fergola advanced the question of variability in the position of the Earth's axis with respect to the solid and rigid mass of the Earth (2). He also proposed a program of latitude observations to be performed in suitably chosen places with identical instruments and uniform methods (3). Fergola's proposal was submitted to the examination of a committee chaired by Giovanni Schiaparelli, Director of the Brera Observatory in Milan, which was charged with preparing a report to the Conference. The detailed and well-documented report concerning the opportuneness of a project of measurements of the periodic, but above all, secular variations in the Earth's axis, presented by Schiaparelli, pleaded for acceptance of Fergola's proposal to start latitude observations in pairs of stations situated more or less on the same parallel with prime vertical meridian instruments. This report was unanimously approved by the Assembly (4).

Although several observatories were invited to begin this program of observations, at the following IGA Conference, held in Berlin in 1886, only two of them had expressed their willingness to participate: the Royal Observatory of 
the Cape of Good Hope and the Columbia College Observatory of New York. Lacking other participants, their willingness remained purely theoretical. Later, only the U.S. Naval Observatory and the Royal Observatory of Lisbon, which were situated more or less on the same parallel, appeared to be interested in setting up a common program of observations according to the recommendations of the IGA (4a).

At the meeting of the IGA Standing Committee in Salzburg in 1888, the partial failure of the resolution of the Rome Conference based on Fergola's proposal was acknowledged. However, upon the suggestion of Foerster, the director of the Berlin Observatory, it was decided to set up another committee in light of the great importance for geodesy and astronomy that the study of the movement of the Earth's axis represented. This new committee, the members of which were Foerster himself, Tisserand, Bakhuyzen (the director of the Leiden Observatory), Helmert (the director of the Central Office in Potsdam) and Weiss (the director of the Vienna Observatory) (5), presented a report, which was later accepted by the Assembly. In this report the importance of the study of variability of the Earth's axis with respect to the Earth was once again stressed, and a new program of latitude observations in four stations was proposed. For the preparation and implementation of this program of observations and the methods to be used in it, the Central Office of the IGA received the sum of DM 4000 (6). On the basis of this resolution, Helmert began work in Berlin with a transit telescope (A. Marcuse, observer) and in Potsdam with a zenith telescope (M. Schnauder, observer), on latitude observations following the Horrebow-Talcott method for the study of the movement of the Earth's axis. Observations began in January 1889 and continued through the spring of the following year. On the suggestion of Theodor Albrecht of the Central Office, analogous observations were conducted at the Strasbourg Observatory (Kobold, observer) and at the Prague Observatory (Weinek and Gruss, observers).

A first report on observations made in Berlin, Potsdam, Strasburg and Prague was presented by Albrecht to the IGA Assembly at its meeting in Paris in the autumn of 1889. On that occasion, it was once and for all acknowledged that the Horrebow-Talcott method was the best for latitude observations (7). A more detailed examination of observations made in Berlin, Potsdam and Prague (those of Strasbourg were invalidated because of an error in the use of the only Talcott level) was made by Helmert and Albrecht at the time of the meeting of the Standing Committee in Fribourg in 1890. This analysis showed the existence of some variations in the latitudes of Berlin, Potsdam, Prague and Pulkovo which could be attributed either to real or apparent variations in the vertical, or to a movement of the rotation axis.

These results led to consideration of the fact that to make the latitude values observed as independent as possible from catalogue errors it was necessary to reconsider Fergola's and Foerster's proposals concerning the need for a suitable distribution of observing stations on the Earth's surface (8). For this purpose a new special committee was appointed, composed of General Annibale Ferrero (chairman), Foerster (supervisor), Bakhuyzen, Helmert, Hirsch (director of the Neuchatel Observatory and perpetual secretary of the Association), and Tisserand, which presented the following conclusions and proposals, later approved unanimously, to the Standing Committee: 
(i) the Committee recognised the importance of continuing latitude observations in Berlin, Potsdam and Prague, and possibly also in Strasbourg;

(ii) the Committee was authorized to organize a latitude station in the Hawaiian Islands in the hemisphere under an agreement with the Coast Geodetic Survey of the United States, and to that end set aside DM 15000, on the condition that within a maximum of five months the Committee, on the basis of a detailed examination of the latitude observations at the other stations, confirmed such a decision;

(iii) as concerned the study of secular variations, the Committee delegated to Schiaparelli and Fergola the task of drawing up an executive proposal on the basis of the plan approved by the Rome Conference in 1883, which also had to be compatible with the Association's financial situation.

During the discussion that preceded the decisions of the special committee and those that followed the proposal, it became evident that among the members of the Standing Committee and the delegates, especially among the French, there was a tendency to judge the question of polar motion as belonging more to the field of astronomy than that of geodesy, and a fear that the cost of projects for the study of polar motion might impede the implementation of other initiatives judged to be of equal interest, such as the purchase of a four-metre long platinumiridium standard for the Bureau International des Poids et Mesures, which was championed by Commander Bassot (9).

\section{The ascertainment of latitude variations of polar origin}

Even at the meeting of the Standing Committee held in Florence in 1891 there was no lack of opposition among the French delegates concerning a greater financial involvement of the IGA in the study of polar motion. On that occasion, Foerster and General Ferrero strenuously upheld the opposite view, insisting on the opportuneness and necessity of the Association's commitment to the organization of further initiatives in the direction of the observation and study of periodic and secular variations in polar motion. For this purpose a new special committee was appointed and composed of the Office of the Chairman of the Standing Committee and of Bakhuyzen, Foerster and Tisserand. At the next and final meeting the name of Giovanni Schiaparelli was added (10).

At the following meeting of the General Conference and of the Standing Committee of the IGA, held in Brussels in September-October 1892, Helmert and Albrecht, on presenting the results of the latitude observations recorded in Berlin, Potsdam, Prague and in the austral station in Honolulu (Hawaii) by Marcuse, who was the observer there, announced that such results clearly showed that the main cause of apparent latitude variations was the motion of the Earth's axis in the Earth's mass. They further announced that the latitude observations conducted in Washington (Rockville) also confirmed previous results (11). These conclusions were also in agreement with those that Chandler had recently obtained from an analysis of long series of latitude observations (12). 
The draft resolution prepared by the Committee appointed in Florence and presented in Brussels by Bakhuyzen, Helmert, Hirsch and Foerster, acknowledged that the latitude observations obtained in Berlin, Potsdam, Prague, Strasbourg and Honolulu, as well as those conducted in Washington (Rockville) and Pulkovo brought to light "des deplacements sensibles et prés ou moins periodiques de l'axe de rotation de la Terre dans le globe terrestre". It then requested that efforts to investigate all aspects of such an important issue be continued so as to provide the astronomic and geodetic works with an exact knowledge of the corrections to apply to latitude, longitude and azimuth observations in order to reduce them to the same mean origin of the Earth's axis. To this end the Central Office of the Association was delegated to act as liaison for the different observatories willing to participate in the enterprise (13).

At the third and final meeting of the Standing Committee at the Brussels Conference, General Ferrero read a letter by Schiaparelli. In this letter the Italian astronomer, on referring to the previous draft resolution, underscored the opportuneness of the Central Office continuing to direct first hand the efforts made by the different independent observatories through latitude observations in the study of the Earth's axis rather than as an intermediary. He also insisted on the need for the Central Office to begin the study of a program of latitude observations at four stations situated on the same parallel. In support of the first part of Schiaparelli's proposal Foerster, Helmert and Bakhuyzen took a stand, but they did not, however, feel that the Association was at that time able to find the financial resources needed to support the organization of the four latitude stations as proposed by Schiaparelli. On this subject Bakhuyzen, in order to integrate the financial efforts necessary to start up the project of the four stations, proposed negotiations between the IGA and the International Astronomical Society represented by the Astronomische Gesellschaft, which had been founded in 1863 .

In the report prepared by the Central Office, which was presented at the meeting of the Standing Committee in Geneva in September 1893, Helmert mentioned the growing interest of the astronomical community for the issue of latitude variations and the importance of the results obtained by Chandler in the definition of the period of free nutation of about 430 days and of an annual period caused by forced nutation (14). However, he once again limited himself to underscoring the need to continue research on latitude variations but with the use of observatories situated on different meridians. During the meeting, Hirsch once again brought up the question of the opportuneness of immediately detailing and preliminarily discussing projects for the organization of a latitude observation service by stations on the same parallel (15).

At the following meeting Foerster, on referring to the resolution of the General Conference in Brussels, pointed out that the desired negotiations with the International Astronomical Society had not begun because of the postponement of its annual meeting, but that in any case the choice of stations and the beginning of latitude observations in at least three of them on the same parallel could no longer be put off. He considered such a project more economical and advantageous than the accumulation of heterogeneous and isolated data from the independent stations (16). At the same meeting Ferrero read a second, more important letter by Schiaparelli. In it, Schiaparelli repeated with strong, scientific arguments that it was necessary to set up permanent monitoring of latitude 
variations and held, in no uncertain terms, that this task should be undertaken by the International Geodetic Association. He also mentioned Fergola's and Marcuse's projects, underscoring the importance of finding four stations on the same parallel with duties closely connected with the study of polar motion.

The importance of Schiaparelli's arguments concerning the study of latitude variations was immediately understood. They represented a clarifying element, not only on the scientific plane, but more importantly on that of the necessity of making different and more difficult decisions on the part of the members of the Standing Committee. In fact, Helmert and Bakhuyzen were still in favour of awaiting developments, but the majority of the Committee, following the interventions of Foerster, Ferrero and Hirsch, decided (five against three), to appoint a new Special Committee, to which were elected Schiaparelli ( 7 votes), Tisserand (6 votes) and Foerster (5 votes), for the purpose of drawing up a draft project to present to the next General Conference (17). This Conference was held in Berlin from 25th September to 12th October 1895, and it was decisive for the future international service for the study of polar motion. On that occasion, in fact, the "New International Geodetic Convention" was adopted.

\section{Approval of the new Convention of the IGA and the organization of the International Latitude Service}

Following the Geneva Conference, and in preparation for the one in Berlin, the Central Office, which for years had been performing the reduction calculations of the independent stations, began, under the direction of Albrecht, an in-depth study to identify the stations of the future service. Similar studies were conducted by Foerster, who proposed four stations on parallel $37^{\circ} 5^{\prime}$ : Licata in Sicily, Shirakava in Japan, Felton in California and Petersburg in Virginia (18).

The overall conditions for Italy's participation in the service had been pointed out in a letter sent by Schiaparelli to Foerster dated 20th February 1894. In it there was also a reference to the mandate the Geneva meeting had assigned to the special committee made up of Schiaparelli, Tisserand and Foerster, three astronomers, the first and last of whom were directors of astronomical observatories. This mandate was to contact the International Astronomical Society (19), and the society of geologists in order to present to these associations the project for an international latitude service for the measurement of polar motion, and assay their interest in participating, even financially, in the enterprise (20). The letter that Foerster as secretary of the special committee must have drafted for delivery to the officials of the Astronomical Society, which he had certainly sent to Tisserand and Schiaparelli beforehand, obtained the wholehearted approval of the latter and of the Italian Geodetic Commission (21). Even Tisserand expressed his generally favorable opinion (22). The letter, which was sent to Hugo Gylden, Chairman of the Astronomical Society, was submitted to the members of this Society during a meeting held at Utrecht in August 1894.

The members of the Astronomical Society expressed themselves favorably as concerned the scientific content of the project and also their possible participation in the drawing up of an executive plan. But they also expressed their unwillingness to participate in the work of checking, calculating and publishing the results (23). A certain number of astronomers, among them Bakhuyzen and 
Tisserand, felt that the question of polar motion belonged more to the field of astronomy than to that of geodesy, and thus were hoping to involve astronomers in the enterprise. But on the practical level it was difficult to believe that the Astronomical Society, which was then the only organization representing a large share of the astronomical community, could represent, given its unofficial nature, a valid interlocutor of the Geodetic Association, which instead had all the requisites for planning, financing and managing such a complex phenomenon, the causes of which were so obscure. On the other hand, at that time many astronomers and astronomical observatories were involved in just-as-important international cooperative ventures, such as the Zone Catalogue promoted by the Astronomical Society itself, and the Carte du Ciel, which had come from an initiative of the Paris Observatory in 1887, and which in 1891 found 18 astronomical observatories seriously involved in the task.

The great undertaking of the service for the observation of latitude in fixed stations located on the same parallel with identical instruments was in any case adopted by the IGA at the Berlin Conference at which, as has been said, a new "Convention" was adopted (24). During the third session of the Conference (1st October 1895) the well-known Articles 6 and 7 of the Convention, which dealt with the annual budget of the Association, previously set at FF 20000 and contributed by member states, were discussed. Passage of the proposal to increase the budget to 75000 francs would obviously have allowed the Association to bear the entire burden of new initiatives, among which the most important was the project for setting up an international latitude service. But opposition to such an increase came mainly from the French and Dutch members of the Standing Committee, since it was their belief that the Association should limit itself to supervising programs calling for international cooperation and cover only the expenses involved in calculations and the publishing of results.

The merit of having shifted attention from purely economic considerations to the scientific proposals, especially the proposal to organize an international latitude service, must go to Hirsch, the Permanent Secretary of the Association, during the lively and heated debate that characterized that meeting. In part, he used the arguments developed by Schiaparelli in his letter read to the meeting of the Standing Committee in Geneva, and he also stated clearly that no initiative, especially the one concerning the international latitude service, could be undertaken by the Association without a budget tailored to the emerging exigencies (25). At the fourth session on 4th October, Article 7, which set the Association's annual budget at FF 75000 , was approved by a vote of four to three (26) and, at least from the financial viewpoint, there appeared to be no more obstacles in the path of the great enterprise.

At the meeting of the Standing Committee in Lausanne the following year (27), Helmert, in his report on the activities of the Central Office of the Association, after presenting the results of variations in the position of the pole deduced from observations in the independent stations and calculated by Albrecht (28), went on to illustrate a study which had been prepared by the Central Office itself, concerning the choice of stations for the future international latitude service for the determination of motion of the Earth's axis (29). The study, presented by Helmert and Albrecht, was based on data of a geographic, seismic, logistic and hygienic and public health nature concerning a certain number of localities situated on different parallels and in different regions of the four continents. 
From the geographic characteristics (latitude $\phi$ and longitude $\lambda$ ) of 12 combinations of four stations situated on the same parallel and of 3 combinations of three stations on three different parallels, the maximum and minimum weights to assign to the values of coordinates $\mathrm{x}$ and $\mathrm{y}$ of the instantaneous pole with respect to the mean pole, deduced from the formula introduced by Kostinsky in 1893, were calculated:

$$
\phi_{i}=\phi_{0, i}+\mathrm{x} \cos \lambda_{i}+\mathrm{y} \sin \lambda_{i}
$$

From these calculations it was found that a small number of combinations, among which was the combination of: Mizusawa (Japan), Cagliari (Italy), Dover (Delaware) and Ukiah (California) situated on parallel $39^{\circ} 8^{\prime} \mathrm{N}$, possessed the best requisites. The discussion following the presentation of the study went into great detail and was quite heated. During this discussion the project drawn up by Marcuse for use in latitude determination with the photographic method (30) was also examined, but the decision on the method and the choice of the combination of four stations was put off to the next General Conference, which was held in Stuttgart in October 1898.

At that conference, upon the proposal of the Central Office, another of the hundredth series of committees was appointed, this time made up of Bakhuyzen, Preston, Bouquet de la Grye, Celoria and Foerster, and assigned the task of formulating an opinion on the report presented by Helmert and Albrecht concerning preparatory work for the international latitude service (31). In this report the following six stations were presented: Mizusawa (Japan), Tchardjui (Russia), Carloforte (Italy), Dover or Gaithersburg (Eastern United States), Cincinnati (Central United States) and Ukiah (Western United States), situated on parallel $39^{\circ} 8^{\prime}$, with a preference for the choice of Mizusawa, Carloforte, Dover or Gaithersburg and Ukiah.

The committee, and afterwards the General Conference, on the whole gave their approval to the Central Office's project and set the beginning of observations in six stations, of which four (Mizusawa, Carloforte, Gaithersburg and Ukiah) were completely financed by the Association, while the other two (Cincinnati and Tchardjui) only partly financed. It was further established that latitude observations would be made visually using zenith telescopes manufactured by the Wanschaff Company, and applying the Talcott method under the supervision of the Central Office. The duration of the campaign was set at five years, at the end of which the opportuneness of continuing the observations would be evaluated (32).

\section{Conclusion}

With this resolution, the issue, which had begun in 1883 with Emanuele Fergola's proposal to organize an international latitude service to verify and study latitude variations based on a program of observations at pairs of stations located on the same parallel at a great distance one from the other, could be considered at an end. The main events are summarized in Table 1. The idea of extending Fergola's project to four or more stations, which was later advanced by Schiaparelli in his well-known letter addressed to the Standing Committee in 1893 and championed by Foerster at the General Conference in Berlin in 
1895, strengthened practical and scientific motivation, and once again brought to the attention of the scientific community the urgent need to implement such an enterprise after Fergola's proposal had seemed to encounter skepticism and a certain lack of interest.

In autumn of 1899 , thanks to the efforts of Helmert and Albrecht at the Central Office, the International Latitude Service officially came into existence. At the four stations entirely financed by the IGA, latitude observations were made with zenith telescopes constructed specifically for the purpose by the Wanschaff Company in Berlin. These telescopes had an aperture of $108 \mathrm{~mm}$ and a focal length of $130 \mathrm{~cm}$. At the Tchardjui and Cincinnati stations, Wanschaff zenith telescopes with an aperture of $68 \mathrm{~mm}$ and a focal length of $100 \mathrm{~cm}$ were used. Observations began at Cincinnati on 1st September 1899, at Tchardjui on 10th September 1899, at Gaithersburg on 2nd October 1899, at Ukiah on 11th October 1899, at Carloforte on 24th October 1899, and at Mizusawa on 16th December 1899.

During 1899 and up to the end of 1900 observations were made by Prof: H. Kimura and Dr. T. Nakano at Mizusawa, Lieutenant-Cólonel Ossipoff at Tchardjui, Prof. G. Ciscato and Dr. E. Bianchi at Carloforte, Mr. Edwin Smith at Gaithersburg, Prof. J.G. Porter at Cincinnati, and Dr. F. Schlesinger at Ukiah.

Together with these observations, the study of polar motion benefitted, at least up to 1903 , from the contribution of observations which had been recorded by the so-called "free" ("independent") stations (see Table 2). This contribution was by no means marginal. It was thanks to these latitude observations that the existence of variations of polar origin were first suspected and later ascertained, thus convincing the majority of astronomers and geodesists, and the IGA itself, to plan and finance the International Latitude Service. Beyond all expectations, the International Latitude Service (ILS), and from 1962 the International Polar Motion Service (IPMS), which benefitted from the precious contribution of the independent stations endowed with instruments that were more modern and accurate than the zenith telescope, continued its valuable activity up to 1979 . The latitude observations made by the stations of the ILS opened the way to the acquisition of knowledge on the physical and dynamic characteristics of the Earth, and even today it can be said that the study of latitude variations and polar motion continues to be looked to when dealing with still unanswered questions concerning the internal structure of the Earth and the crust motion. 
Table 1. The Question of Latitude Variation of Polar Origin and Decisions Made Within the International Geodetic Association (18831898).

- General Conference, Rome, 1883: Fergola's proposal, Special Committee: Schiaparelli, Bakhuyzen, Cutts, Villarceau, Christie

- Meeting of the Standing Committee, Salzburg, 1888, [Study] Committee: Foerster, Bakhuyzen, Helmert, Tisserand, Weiss

- Meeting of the Standing Committee, Fribourg, 1890, [Study] Committee: Ferrero, Foerster, Bakhuyzen, Helmert, Hirsch, Tisserand

- Meeting of the Standing Committee, Florence, 1891, Special Committee: Office of the Chairman of the Standing Committee, Foerster, Bakuyzen, Schiaparelli, Tisserand

- Meeting of the Standing Committee, Geneva, 1893: project for preparation of the ILS, Special Committee: Schiaparelli, Foerster, Tisserand General Conference, Berlin, 1895: approval of the "New International Geodetic Convention"

- Meeting of the Standing Committee, Lausanne, 1896: Proposal of the Central Office [Helmert and Albrecht] concerning the choice of the international latitude stations

- General Conference, Stuttgart, 1898, Committee for the choice of the four + two stations and preparation of the ILS: Bakhuyzen, Preston, Bouque de la Grye, Celoria, Foerster 
Table 2. Contributions to the Study of Polar Motion by Latitude Observations made in the So-called "Free" [Independent] Stations and Observatories (1890-1903).

- Th., Albrecht, Bericht uber den gegen wartigen Stand der Erdforschung Breitenvariation, (1890.0-1895.2), Berlin, 1896, [Kasan, Pulkowa, Wien, Prag, Berlin, Potsdam, Strassburg, Karlsruhe, Bethlehem, Rockville, San Francisco, Honolulu]

- Th., Albrecht, Bericht uber den Stand der Erdforschung del Breitenvariation, (1890.0-1897.5), Berlin, 1898 [Tokyo, Kasan, Pulkowa, Warschau, Kapstadt, Prag, Neapel, Potsdam, Lyon, New York, Philadelphia, Washington]

- Th., Albrecht, Bericht uber den Stand der Erdforschung der Breitenvariation, (1895.0-1898.7), Berlin, 1899 [Tokyo, Taschkent, Kasan, Pulkowa, Warschau, Prag, Potsdam, Strassburg, Lyon, New York, Philadelphia, Washington]

- Th., Albrecht, Bericht uber den Stand der Erdforschung der Breitenvariation, (1895.0-1899.8), Berlin, 1900 [Tokyo, Kasan, Moskau, Pulkowa, Prag, Potsdam, Lyon, New York, Philadelphia, Washington]

- In 1901 the results of latitude observations in the independent stations were published together with those of the ILS ( $c f$. , Rapport sur l'activité du Bureau Central de l'AGI en 1900, Leiden, 1901, 6). The number of independent stations who supplied the results of their latitude observations during 1901 was reduced to four: Tokyo, Heidelberg, Leiden and Philadelphia ( $c f$., Rapport sur les traveaux du Bureau Central de l'AGI en 1902, Leiden, 1903, 4-5).

- In 1902-1903 only the Leiden Observatory continued its latitude observations as an independent collaboration ( $c f$. , Rapport sur les traveaux du Bureau Central de l'AGI en 1903, Leiden, 1904, 5). 


\section{References}

(1) In his research on the effects that movements of large masses could exert on the mobility of the Earth's inertia axis, George Darwin took into consideration both the hypothesis of a rigid Earth (cf., Darwin G.H., "On the influence of geological changes on the Earth's axis of rotation", Philos. Trans., 157, 1879, 271-312), and the hypothesis of a viscous Earth ( $c f$. , Darwin G.H., "On the precession of a viscous spheroid and on the remote history of the Earth", Philos. Trans., 170, 1879, 447-538).

(2) The hypothesis that the Earth was substantially rigid was then generally accepted. In the report to the special committee appointed by the Rome Conference to examine Fergola's project presented by Schiaparelli, we find: "Il ne faut pas se dissimuler, que dans le dernier temps il y a une tendence à considerer la Terre comme un corp doué d'une grande rigidité". (cf., Comptes-Rendus des séances de la VII.me Conference Générale de l'Association Geodesique Internationale, Berlin, 1884, 208.

(3) Cf., Comptes-Rendus, cit. in the previous note, 157. The text of the proposal presented by Fergola to the Rome Conference is also given in: Proverbio E., "L'organizzazione del Servizio Internazionale delle Latitudini: il contributo italiano", Giornale di Fisica, Vol XXXVII (3), 1996, note 13.

(4) "Rapport sur le project d' operations proposé par M. le professeur Fergola dans la séance du 16 octobre 1883 pour l'etude des mouvements de l'axe de rotation de la Terre dans son interieur, et des variations de latitudes qui en dépendent" (cf., Comptes-Rendus, ibid., 206-213). (4a) Cf., Comptes-Rendus des séances de la Conférence Générale de l'AGI et de la Commission Permanente, reunies a Berlin du 27 octobre a 1 novembre 1886, Berlin, 1887, 75-78.

(5) Comptes-Rendus des séances de la Commission Permanente de l'AGI, reunie a Salzbourg du 17 au 23 septembre 1888, Berlin, 1889, 29-30.

(6) Comptes-Rendus, ibid., 33-34.

(7) Comptes-Rendus des séances de la IX Conférence Générale de l'AGI et de la Commission Permanente, reunies a Paris du 13 au 19 octobre 1889, Berlin, 1890, 20-21, 32, Annèxe A.IX.

(8) Comptes-Rendus des séances de la Commission Permanente de l'AGI, réunie à Friebourg du 15 au 21 septembre 1890, Berlin, 1891, 61-68.

(9) Comptes-Rendus, ibid., 90-97.

(10) Comptes-Rendus des séances de la Commission Permanente de l'AGI, réunie a Florence du 8 au 17 octobre 1891, Berlin, 1892, 23-26, 29-31.

(11) Comptes-Rendus des séances de la Dixiéme Conference Generale et de la Commission Permanente de l'AGI, réunies a Bruxelles du 27 septembre au 7 octobre 1892, Berlin, 1893, 15-19. 
(12) Chandler S.C., "On the Variation of Latitudes", Astron. Journal, 248, $1891,59-61 ; \mathbf{2 4 9}, 1891,65-70 ; \mathbf{2 5 0}, 1892,75-79 ; \mathbf{2 5 1}, 1892,83-86$.

(13) Comptes-Rendus, cit. in Note 11, 37-39.

(14) Chandler S.C., "On the Variation of Latitude", Astron. Journal, 267, $1892,17-22 ; \mathbf{2 7 2}, 56-62 ; \mathbf{2 7 3}, 65-72 ; \mathbf{2 7 7}, 97-101$.

(15) Comptes-Rendus des séances de la Commission Permanente de l'AGI, rèunie a Genève du 12 au 17 septembre 1893, Berlin, 1894, 13-18.

(16) C-R, ibid., 41.

(17) C-R, ibid. 42-47.

(18) Foerster W., Denkschrift zur Begrundung der in dem Ert Wurfe einer neuen Uberfeinkunf fur die Internationale Erdmessung vorgschlagenen Dotationserhogung, Berlin, 1895.

(19) The Astronomische Gesellschaft was founded in Heidelberg in 1863. Although the Association was originally German, it was from the beginning open to astronomers of other countries and a promoter of international cooperative initiatives. The well-known A.G. Zone Catalogue of the boreal sky was organized by it in 1869. The statute of the Association established that members should come from different nations. At its first meeting there were participants from ten different countries.

(20) From the Comptes-Rendus, Note 15, 45, I cite the following passage which sums up quite well the orientation of the members of the Committee during the meeting held in Geneva in 1893 as concerns the question of cooperation with the Astronomische Gesellschaft: "En resumé M. Bakhuyzen est d'avis que cette interessant question [the determination and study of polar motion] est plutot de domaine de l'astronomie que de la géodésie, mais que la cooperation des deux sciences serà utile aussi au sein d'une Commission spéciale telle qu'on l'a proposée. M. Ferrero répond que l'Association Géodésique, qui a eu le mérite d'avoir la prenière attiré l'attention du monde scientifique sur la variation des latitudes, a aussi l'obligation de pursuivre et de mener à bonne fin ces importantes recherches. Du reste elle a sur la Société Astronomique, dont la coopération est sans doute désirable, l'avantage d'ètre une organisation officielle de vint-huit Etats et de jouir des ressources financières accordées par ceux-ci, ce qui lui permet de publier plus vite les résultats de ses travaux. M. Foerster appuie cette manière de voir par la considération que la Commission special, qu'on propose de nommer, pourra précisément se mettre sans dificulté en relation avec les Sociétés astronomique et géologique. Une entente avec les astronomes et les géologues fera certainement surgir de nouveaux points de vue autour de cette question". The meeting of the Astronomical Society, during which the proposal for cooperation was to be presented, did not take place in 1893 as scheduled, and even relations with the geological societies in that year were no more than informal contacts (cf., C-R, ibid., $40)$. 
(21) In the letter to Foerster dated 20th February 1894, which appeared in the Denkschrift, cit. in Note 18, Schiaparelli wrote: "Nous donnons notre intière adhesion au projet de lettre que vous avez proposé d'ecrire à l'Astronomische Gesellschaft [...]".

(22) As concerns the proposal to involve the Astronomical Society in the planning of the future latitude service, on 11th March 1894 Tisserand wrote to Foerster: "J'approuve votre idée de saisir la Societé astronomique de l'important question de la variabilité des latitudes; j'ai toujours pensé en effet que cette question présentait plus d'importance pour l'astronomie que pour la géodésie. Mais je crois que la Societè astronomique devrà s'occuper des méthodes d'observation, plutot que de l'organisation d' un Bureau international venant s'ajouter a ceux que nous possédons déjà. La question n'est par mure ancore. Je ne crois pas que l'on puisse affirmer, comme cela est dite dans le projet de lettre, que toute théorie serà impuissant à prevoir les variation de la latitude. Ce serait, à mon avis, porter un jujement prématuré sue les recherches de $\mathrm{M}$. Chandler, et sur les travaux théoriques de M. Newcomb" (cf., Denkschrift, cit. in Note 18).

(23) Cf., Foerster, Denkschrift, cit. in Note 18, 10. Here is the text of the letter and the resolution: "Der Forstand der Astronomische Gesellschaft ist swar nicht in der Lage gewesen, die Einzel heiten des in Ihrer Denkschrift von 5 Mai 1894 dargelegten Organisation und Beobachtungplanes einer Prufung und begutachtung $z u$ unterziehen, hat sich jedoch in Beschaftigung mit der betreffenden Angelegemheit in seiner Mehrheit folgendermaassen erklart:

1. Der Vorstand der Astronomische Gesellschaft spricht sich fur die Zweckmassigkeit der Errichtung eines regelmassigen Beobachtungsdienstes fur die Bestimmungen der Lagen-Aenderungen der Erdaxxe aus;

2. Der Vorstand der Astronomische Gesellschaft ist gerne berei in einer eventuell festzustellenden Weise auf Wunsch sich uber die Ausarbeitung der Planes zu aussern. Die Frage ob die Astronomische Gesellschaft sich eine fortlaufende Mitwirkung bei der Controle und der zweckmassigen Gestaltung der Berechnung und Veroffentlichungen zu sichern wunsche, wind verneint." Hugo Gyldén

(24) The text of the "New International Geodetic Convention" is published in Appendix IV to Comptes-Rendus des séances de la onzieme Conférence Générale del l'AGI et de la Commission Permanente, réunies a Berlin du 25 septembre au 12 octobre 1895, Berlin, Vol. I, 1896, 284-287.

(25) On the discussion dealing with Articles 6 and 7 of the new convention, see the C-Rs cited in the previous note, 234-238.

(26) ibid., 138.

(27) Comptes-Rendus des séances de la Commission Permanente de l'AGI, reunie à Laosanne du 15 au 21 octobre 1896, Berlin, 1897.

(28) "Bericht uber den gegenwartingen Staud der Erfoschung der Breitenvariation", in C-R cited in the previous note Beilage A.I, 127-129. 
(29) "Uber der Wahl der Stationen fur den Internationalen Polhohendienst", ibid., Beilage A.II, 127-129.

(30) ibid., Beilage A.V, A.VI and A.VII, 173-178, 179-203, 205-220.

(31) Comptes-Rendus des séances de la douziéme Conférence Générale de l'AGI, reunie a Stuttgart du 3 au 12 octobre 1898, Berlin, 1899, Beilage A.II: Helmert and Albrecht, "Bericht uber die vorbereitungen fur die internationalen Polhohendienst", 201-209.

(32) In the light of its historical importance, below is the unabridged resolution adopted unanimously by the special committee and presented to the Stuttgart Conference on 10th October 1898 ( $c f .$, ibid., 135):

1. La Conference décide que l'étude international de la variation du Pole, prevue au paragraphe 4 de l'Art. 6 de la Convention de 1896, serà entreprise à dater du 1899, sous la direction et la responsabilité du Bureau central e sous le control du Bureau de l'Association (voir Art. 7 de la Convention).

2. A cet effet, elle adopt le programme présenté par le directeur du Bureau central, qui prévoit six stations situées sous le meme parallèle, dont quatre seront entièrement au frais de l'Association et deux, celle de Tchardjui, en Russie, et celle de Cincinnati aux Etats-Unis, seront subventionnées par l' Association. Elle accepte avec une vive satisfaction le concours gracieusement offert par la Russie et les Etats-Unis pou ces deux dernières stations.

3. Les frais de cette entreprise seront prélevé sur la dotation prévue à l'alinéa 4 de l'Art. 6 de la Convention.

4. La Conférence décide que les observations a faire dans ce but seront continuées d'abord pendent une période de cinq années consécutives. A la fin de cette périod, la Conférence Générale se prononcera sua la continuation éventuelle de ces observations, ainsi que sue le modifications que l'expérience aura suggérée, qunt aux méthodes à employer.

5. Pendent ces cinq années, les observations seront faites d'après la méthode de Talcott, en se conformant aux indications données par le Rapport sue les recherches préparatoires pour les déterminations de la variation du Pole, présenté à la Conference par le MM. Helmert et Albrecht.

6. Des recherches préliminaires ayant indiqué que la méthode des observations visuelles offre actuellement plus de garanties que la méthode photografique, et que cette dernière exigerait des dépenses dépassant les credits disponible, la Conférence décide que, pendent les cinq premières années d'observations, on se servira de la méthode visuelle.

7. Comme il est d'un grand intéret, surtout pour la détermination de la variation périodique annuelle de la position de l'axe terrestre, l'éliminer autant que possible les erreurs systématiques annuelles par des observations faites dans une grand nombre de stations, la Conference décide que le Bureau invitera les onservatoires qui s'intéressent à cette 
entreprise à continuer ou à commencer les déterminations de la variation de la latitude, en leur laissant toute liberté dans l' emploi des méthode set des instruments.

8. La Conférence décide que le Bureau central est autorisé à procéder aussitot que possible à l'organisation de l'entreprise. De même, le Bureau central est autorisé à régler les condition d'installation et de fonctionnement des stations de latitude, y compris les droits de propriété des appareils et des installations. Dans le cas où il y aurait lieu de s'entendre avec les Gouvernements, le Bureau de l'Association se chargera, d'aprés l'Art. 4 de la Convention, de la correspondance et de la ratification des traités. 


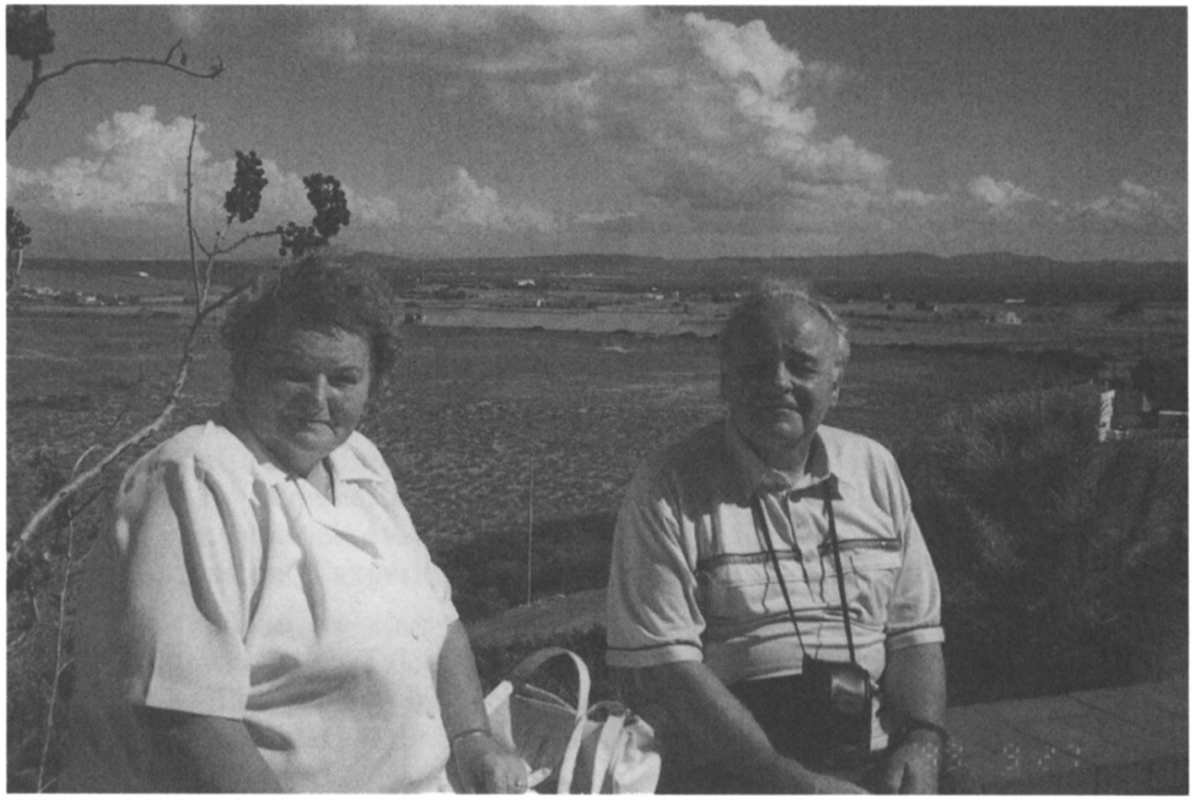

Edith and Joachim Höpfner 